\title{
Leucocyte populations in ectopic tubal pregnancy
}

\author{
U EARL, D P LUNNY, J N BULMER
}

From the Department of Pathology, University of Leeds, Leeds

SUMMARY Leucocytes at the ectopic implantation site in 10 cases of early tubal pregnancy were characterised with a series of monoclonal antibodies using an indirect immunoperoxidase technique on cryostat sections. Most were HLA-DR positive macrophages, and there were a small number of mature T lymphocytes (UCHT1 and Dako-T1 positive cells). These results were compared with those reported in normal first trimester intrauterine pregnancies, and the contributions of the various leucocyte types to successful implantation at both the ectopic and intrauterine sites were assessed.

The developing embryonic and extraembryonic tissues of the placenta carry an assortment of tissue specific and transplantation antigens, some of which are foreign to the maternal immune system. Despite widespread infiltration of maternal decidua, myometrium and uterine vessels by semiallogenic extravillous cytotrophoblast, a detrimental immune response between mother and fetus does not occur.

In early intrauterine pregnancy, however, large numbers of potential maternal immune effector cells are dispersed throughout the decidua lining the uterus, and leucocytes aggregate particularly around spiral arteries, the degenerating glands of the decidua basalis, and in areas of trophoblastic invasion. ${ }^{1-3}$ Immunohistological characterisation of this infiltrate has shown that it mainly consists of macrophages and T lineage lymphocytes. ${ }^{3-5}$ The distribution and antigenic phenotype of the $T$ lineage cells suggests that they correspond to specific endometrial granulocytes, sometimes referred to as Körnchenzellen or K cells. ${ }^{34}$ Endometrial granulocytes form a unique population of endometrial leucocytes that is prominent in the late secretory phase of the menstrual cycle and in first trimester decidua. Morphologically, endometrial granulocytes differ from circulating polymorphonuclear leucocytes in having phloxinophilic cytoplasmic granules, and an oval, lobulated, pyknotic and hyperchromatic lymphocyte-like nucleus.

The functions of leucocyte populations at intrauterine implantation sites in humans have not been fully determined. This contrasts with the findings in murine decidua, in which there is evidence that leucocyte populations modulate the maternal immune response. $^{6}$

Successful pregnancy does not depend on an intrauterine environment. Ectopic pregnancy usually

arises in the fallopian tube, and progresses until tubal rupture or gross tubal distension occurs, necessitating surgical removal. Rarely, tubal pregnancy progresses to term with delivery of a normal infant. ${ }^{7}$ Trophoblast in ectopic pregnancy is identical with normal first trimester intrauterine trophoblastic tissue in the first trimester, with regard to the expression of trophoblast and major histocompatibility complex antigens, and the localisation of pregnancy related hormonal products. ${ }^{89}$ Ectopic pregnancy, therefore, provides an excellent opportunity to study early placental development, and immunological interactions between mother and fetus.

In this report we have characterised the leucocytic infiltrate at the ectopic tubal implantation site and compared the findings with those reported in normal intrauterine pregnancy.

\section{Material and methods}

Ten specimens of tubal pregnancies were received fresh within 30 minutes of surgical removal. Tubal rupture had occurred in one case, and a macroscopically normal fetus was present in two of the specimens. Five millimetre cubes of tissue were dissected to include tube wall adjacent to the pregnancy implantation site. Tissue blocks were snap frozen in isopentane cooled in liquid nitrogen (BDH, Poole, Dorset), and then stored in liquid nitrogen until use. In seven cases the gestational age of the specimen was known, and these ranged from two to 10 weeks after the last menstrual period. Further blocks were fixed in formalin and routinely processed for diagnostic purposes.

Endometrial curettings were taken at the time of salpingectomy in four cases and examined after routine fixation in formalin and processing.

The table gives details of the nine murine mono- 
Table Specificities, sources, and dilutions of monoclonal antibodies used

\begin{tabular}{|c|c|c|c|}
\hline Monoclonal antibody & Specificity detected & Source/reference & Dilution \\
\hline $\begin{array}{l}\text { F-10-89-4 } \\
\text { UCHT1 } \\
\text { Dako-T1 }\end{array}$ & $\begin{array}{l}\text { Leucocyte common antigen } \\
\text { Mature T lymphocytes (CD3) } \\
\text { Mature T lymphocytes (CD5) } \\
\text { proportion of immature B lymphocytes }\end{array}$ & $\begin{array}{l}\text { Serotec, Bicester, UK }{ }^{10} \\
\text { Unipath, Bedford, UK }{ }^{11} \\
\text { Dakopatts A/S, Denmark }\end{array}$ & $\begin{array}{l}1 / 100 \text { peritoneal exudate } \\
1 / 20 \text { purified immunoglobulin } \\
1 / 10 \text { culture supernatant }\end{array}$ \\
\hline $\begin{array}{l}\text { Dako-T2 } \\
\text { OKT } 11 \\
\text { OKT } 8\end{array}$ & $\begin{array}{l}\text { T lineage cells (CD7) } \\
\text { E rosette receptor (CD2) } \\
\text { Peripheral T cells (CD8) } \\
\text { cytotoxic/suppressor subset }\end{array}$ & $\begin{array}{l}\text { Dakopatts A/S, Denmark } \\
\text { Ortho Diagnostics, UK } \\
\text { Ortho Diagnostics, UK }\end{array}$ & $\begin{array}{l}1 / 10 \text { culture supernatant } \\
1 / 20 \text { purified immunoglobulin } \\
1 / 20 \text { purified immunoglobulin }\end{array}$ \\
\hline $\begin{array}{l}\text { Dako-Macrophage } \\
\text { Anti-Leu-M3 } \\
\text { M1/70 } \\
\text { Dako-Pan-B } \\
\text { TG1 }\end{array}$ & $\begin{array}{l}\text { Tissue macrophages } \\
\text { Tissue macrophages } \\
\text { C3b-receptor } \\
\text { B lymphocytes (CD22) } \\
\text { Granulocytes, } 10 \% \text { of monocytes }\end{array}$ & $\begin{array}{l}\text { Dakopatts A/S, Denmark } \\
\text { Becton-Dickinson, USA } \\
\text { Serotec, Bicester, UK } \\
\text { Dakopatts A/S, Denmark } \\
\text { PCL Beverley, University College } \\
\text { Hospital, London }\end{array}$ & $\begin{array}{l}1 / 20 \text { culture supernatant } \\
1 / 20 \text { purified immunoglobulin } \\
1 / 1 \text { culture supernatant } \\
1 / 10 \text { culture supernatant } \\
1 / 1 \text { culture supernatant }\end{array}$ \\
\hline CR3/43 & $\begin{array}{l}\text { Non-polymorphic class II MHC } \\
\text { products (DR, DP, DQ) } \beta \text { chain }\end{array}$ & & $1 / 10$ culture supernatant \\
\hline DA6.231 & $\begin{array}{l}\text { Non-polymorphic class II MHC } \\
\text { products (DR, DP, DQ) } \beta \text { chain }\end{array}$ & 14 & $1 / 10$ culture supernatant \\
\hline
\end{tabular}

clonal antibodies and one rat monoclonal antibody (M1/70) used. ${ }^{10-14}$

Serial $6 \mu \mathrm{m}$ cryostat sections were cut, dried in air overnight, fixed in acetone for 10 minutes, wrapped in foil, and stored at $-20^{\circ} \mathrm{C}$. After rehydration in Tris buffered saline, pH 7.6 (TBS), monoclonal antibodies were applied using a standard indirect immunoperoxidase technique. ${ }^{3}$ An appropriate negative control was included for each case. Sections were lightly counterstained with Harris's haematoxylin and mounted in synthetic resin.

Sections measuring $5 \mu \mathrm{m}$ were fixed in formalin and processed routinely before being stained by the standard haematoxylin and eosin method.

\section{Results}

\section{FORMALIN FIXED TISSUES}

Chorionic villi were present in all specimens, and in six cases abundant extravillous cytotrophoblast infiltrated the fallopian tube wall and vascular spaces. Chronic inflammatory cells of lymphocyte and histiocyte morphology were present at the implantation site and showed some tendency to aggregate around congested blood vessels. No consistent association between chronic inflammatory cells and chorionic villi or extravillous trophoblast was seen. Plasma cells were rarely seen. Acute inflammatory cells were identified in areas of tubal haemorrhage and necrosis. Convincing evidence of previous salpingitis, represented by tubal diverticulae proximal to the ectopic implantation or hydrosalpinx, was seen in two cases. Focal decidualisation of the tubal mucosa was seen in three specimens.

All four endometrial samples showed secretory change, and in two there was an Arias-Stella reaction. Decidualised stromal fragments were present in only one specimen. Endometrial granulocytes were identified in all cases.

\section{FROZEN TISSUES}

All specimens included tube wall with residual epithelium. Implanting chorionic villi and infiltrating extravillous trophoblast were present in three cases. Cells bearing leucocyte common antigen (LCA) were identified by the antibody F10-89-4. There were substantial numbers of leucocytes in all specimens, either dispersed randomly, or forming interstitial aggregates (fig 1). There was no consistent association of leucocytes with vascular structures or implanting chorionic villi.

More than $75 \%$ of the total interstitial leucocytes were stellate and labelled with the macrophage markers Dako-Macrophage and anti-Leu-M3 (fig 2). Serial sections labelled with CR3/43 or DA6.231 showed that these macrophages uniformly expressed nonpolymorphic determinants of class II MHC antigens (figs $3 a$ and $b$ ).

A smaller proportion of interstitial leucocytes, at most $25 \%$ of LCA positive cells, were small round cells. They were diffusely dispersed and showed no association with vascular or trophoblastic tissues. These cells were reactive with the mature pan-T lymphocyte markers UCHT1 and Dako-T1, and also in varying proportions with the $T$ lineage markers Dako-T2, OKT11, and the suppressor/cytotoxic subset marker OKT8; T8 positive cells were usually less abundant than T1- or T2-positive cells (fig 4). Where some aggregation of $\mathrm{T}$ cells occurred, a variable amount of reactivity was observed with the class II MHC markers in consecutive sections, and this reactivity was independent of macrophages associated with the $\mathrm{T}$ lymphocyte aggregates. It proved too difficult, however, to identify individual $\mathrm{T}$ lympho- 


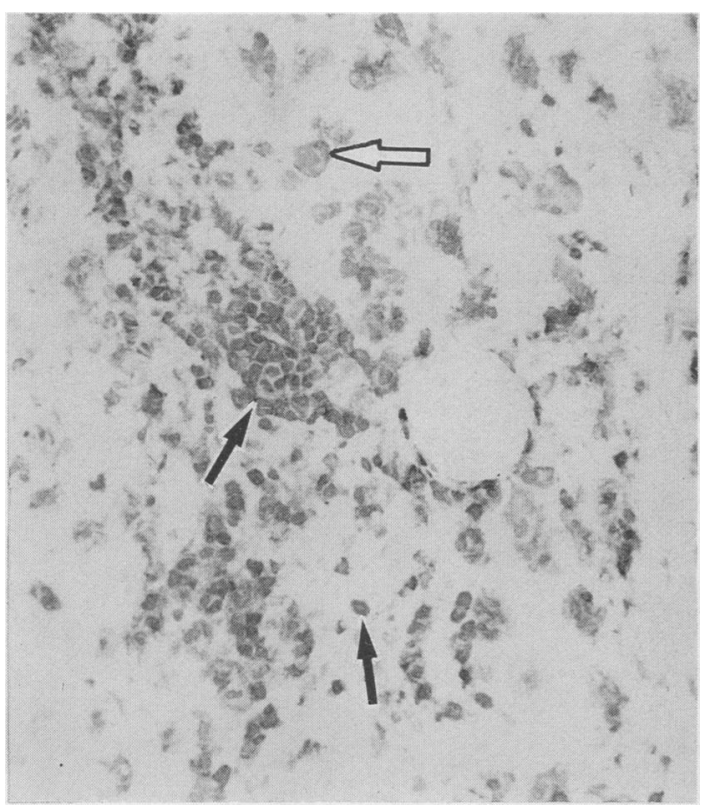

Fig 1 Interstitial leucocytes labelled with leucocyte common antigen marker F-10-89-4. There are two cell types-round cells (small arrows) and larger, irregular, stellate cells (arrowhead). (Haematoxylin counterstain.)

cytes and assess their HLA-DR state with serial sections alone.

Occasional interstitial cells were reactive with $\mathrm{M1} / 70$, which is directed against the $\mathrm{C} 3 \mathrm{~b}$ receptor, carried by monocytes, granulocytes, and a proportion of B cells. A few interstitial cells were reactive with Dako-Pan-B (B lymphocyte marker) or TGl (granulocyte marker).

A constant population of leucocytes was present in the basal layer of the epithelium of the fallopian tube. These intraepithelial leucocytes labelled as mature $T$ cells and showed variable OKT8 positivity.

The stromal Hofbauer cells of fetal chorionic villi labelled with F10-89-4 and were reactive with macrophage markers but not with CR3/43 or DA6.231. Tubal epithelium and vascular structures were reactive with markers of class II MHC products, as previously described. ${ }^{15}$

\section{Discussion}

The presence of a chronic inflammatory cell infiltrate around the implantation site in tubal pregnancy has been well documented, and as in the present study, seems to be related to the pregnancy tissues present, and not to pre-existing chronic salpingitis. ${ }^{16}$ Using a series of immunohistological markers, we have shown that most of the leucocytes at, and adjacent to, the implantation site in ectopic pregnancy are HLA-DR positive macrophages; in the normal non-pregnant fallopian tube these form only a small proportion of the total. ${ }^{15} 17$ Extensive numbers of macrophages defined by morphology, immunohistology, and histochemistry have been reported in normal intrauterine tissues in the first trimester, particularly in areas of trophoblastic invasion, and around spiral arteries and endometrial glands. ${ }^{4}$ The association of macrophages with a pronounced lymphocytic infiltrate around first trimester intrauterine glands, has led to speculation that there may be a local immune response to glandular epithelium. ${ }^{5}$ At the ectopic implantation site, the influx of macrophages appear to be randomly distributed, with no predeliction for tubal epithelium, vascular structures, or trophoblastic tissues. This may be due in part to the different responses of tubal mucosa and endometrium to pregnancy. Although derived from a common Mullerian duct origin, tubal mucosa differs from endometrium in its relative deficiency in progesterone mediated decidualisation. Endometrial glands show a series of morphological changes throughout pregnancy; initially they appear hypersecretory, but later they involute so that by the third trimester they appear only as slit shaped channels. ${ }^{18}$ Furthermore, the epithelial antigenic phenotype changes, so that early in gestation the glands lose class I MHC determinants and aquire novel antigens expressed by trophoblastic cells. ${ }^{19}$ Fallopian tube epi-

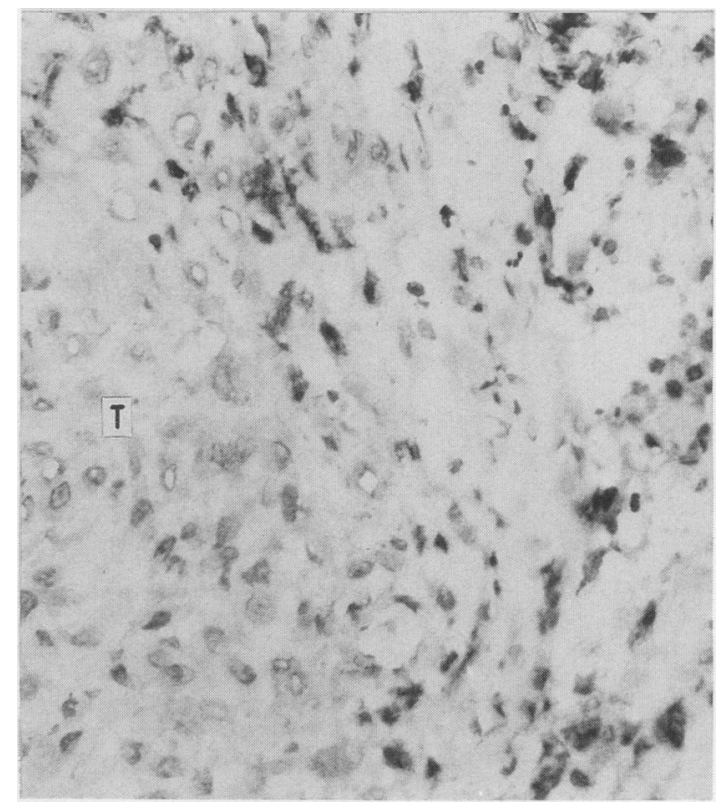

Fig 2 Stellate interstitial leucocytes labelled with Dako-Macrophage adjacent to infiltrating trophoblast $(T)$. (Haematoxylin counterstain.) 


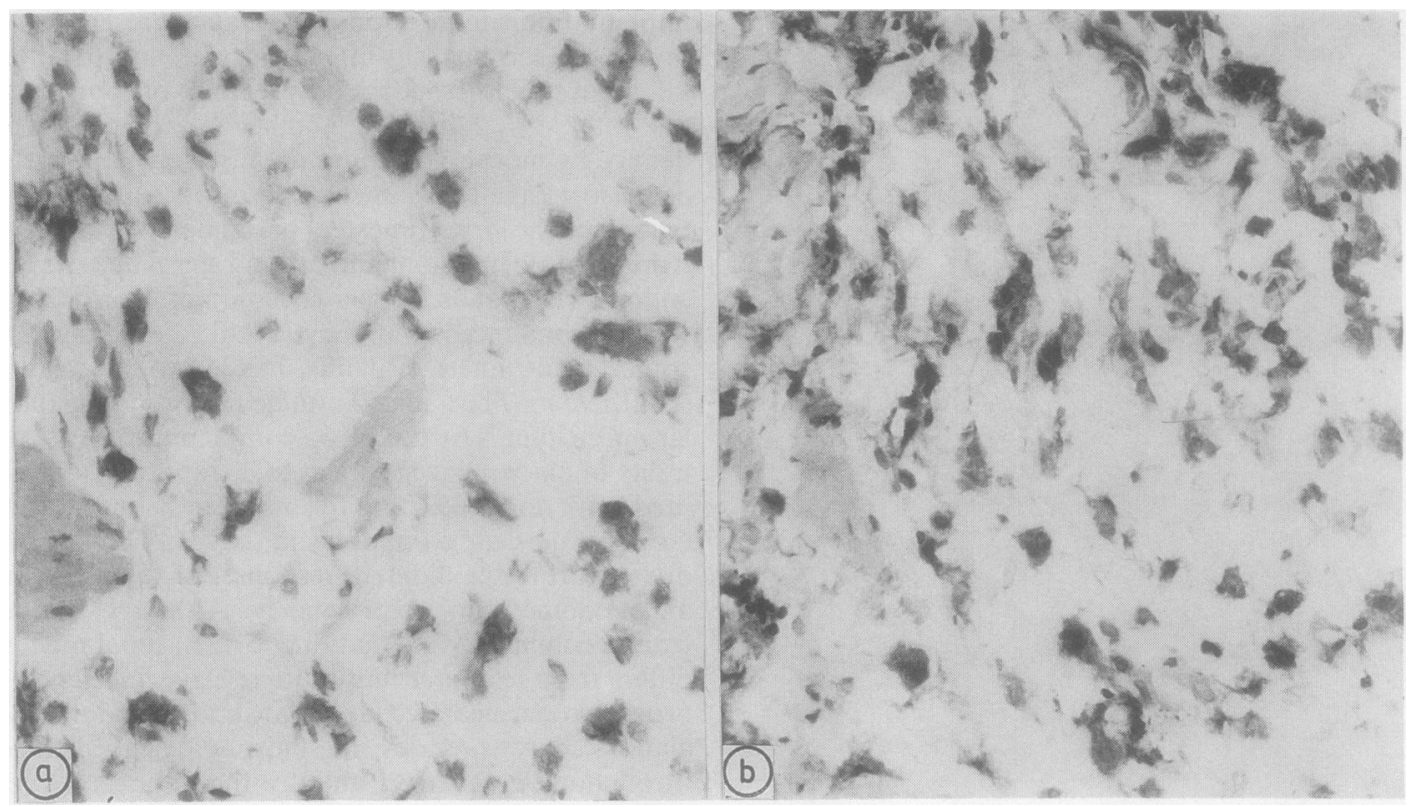

Fig 3 Consecutive sections showing interstitial leucocytes reactive with (a) Dako-Macrophage and (b) class II MHC marker DA6.231. (Haematoxylin counterstain.)

thelium does not show morphological changes in ectopic pregnancy nor is there loss of class I MHC surface antigens, although changes in expression of HLA-D locus products have been described. ${ }^{815}$

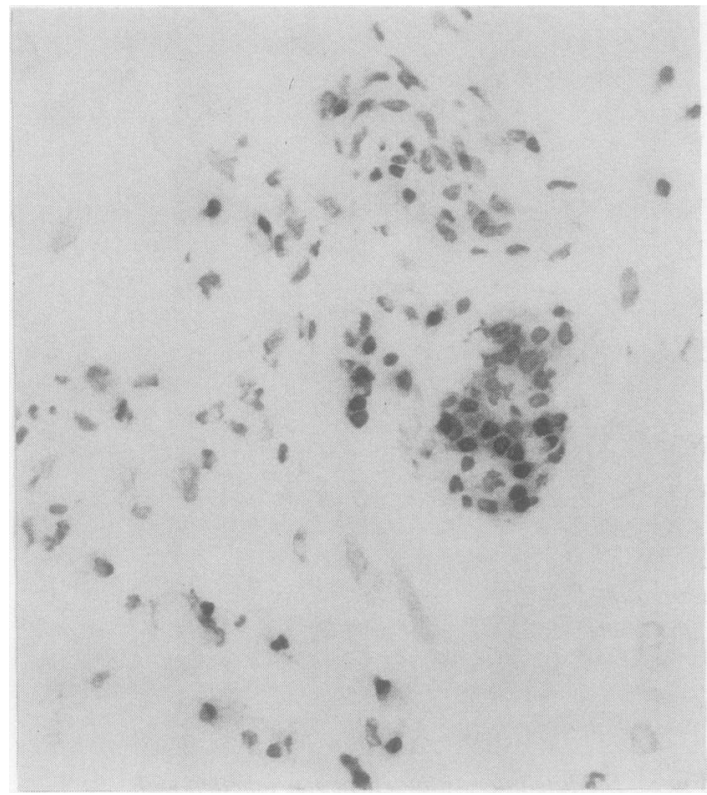

Fig 4 Small round interstitial leucocytes labelled with pan-T lymphocyte marker, UCHT1. (Haematoxylin counterstain.)
The role of macrophages in normal and ectopic pregnancy may be primarily phagocytic - that is, acting to remove tissue debris - or it may also be concerned with the immunological properties of antigen processing and presentation. In murine decidua there is evidence that macrophages regulate the activities of other immunocompetent cells through the release of prostaglandin E2, which inhibits the production of cytotoxic T lymphocytes. ${ }^{20}$

Classical $\mathrm{T}$ lymphocytes formed a much smaller proportion of the leucocytes present at the ectopic implantation site. No $T$ lineage cells bearing the $E$ rosette receptor and immature $T$ cell markers but lacking peripheral $\mathrm{T}$ cell markers, were shown. Such $T$ lineage cells have been reported in first trimester $?$ intrauterine decidua, both distant from and adjacent $\frac{D}{O}$ to the implantation site. ${ }^{3}$ These cells outnumber classic $T$ cells, expressing the mature $T$ cell phenotype by $N$ a ratio of 10:1, and are thought to correspond to the $N$ endometrial granulocytes present in routinely pro- N cessed tissue. ${ }^{3}$ Immunohistological characterisation $\omega$ of these cells in frozen tissue is impeded by the disruption through freezing of their distinctive $\stackrel{\circ}{=}$ eosinophilic and phloxinophilic cytoplasmic granules.

Endometrial granulocytes were once thought to be derived from endometrial stromal cells, and to secrete $\frac{T}{0}$ relaxin in preparation for menstruation. ${ }^{21}$ Recent $\frac{\vec{D}}{\Phi}$ studies, however, have shown that these cells may be $\frac{\rho}{\mathbb{D}}$ derived from bone marrow and undergo further mor- $\varnothing$ phological and phenotypic differentiation within? 
endometrium. ${ }^{23}$ Endometrial granulocytes are prominent in late secretory and menstrual phase endometrium and in first trimester decidua. Their function is unknown, but their absence at the ectopic gestation site makes it unlikely that they participate in local immune modulation of materno-fetal cellular interactions and blastocyst implantation. A small granulated lymphocyte has been shown in murine decidua; this produces a non-MHC dependent, soluble, suppressor factor which inhibits generation of antipaternal cytotoxic lymphocytes. ${ }^{6}$ Suppressor activity has been reported in human decidual explants $^{22}$; this suppression seems to originate from small lymphocyte-like cells. ${ }^{2324}$ Decidualisation of endometrial stroma often occurs in ectopic pregnancy, although as we confirmed, it is usually focal and patchy. ${ }^{1625}$ Soluble suppressor factors produced by granulated suppressor cells within uterine decidua may act at a distant ectopic implantation site to permit blastocyst implantation and development.

The presence of leucocyte and macrophage markers, but the absence of HLA-DR antigens on placental Hofbauer cells at the ectopic gestation site, agrees with results reported for normal intrauterine tissues in the first trimester and reflects the early gestational ages of the ectopic specimens. ${ }^{426}$

In conclusion, ectopic pregnancy differs from normal intrauterine pregnancy in that it has no specialised $\mathrm{T}$ lineage cells at the implantation site. Large numbers of macrophages are present both in ectopic and intrauterine pregnancy tissues. Local immune modulation of maternal cytotoxicity, in response to foreign fetal antigens, may revolve around production of soluble suppressor factors by macrophages which down regulate the activities of other immunocompetent cells. Conversely, soluble factors derived from cells within uterine decidua may be capable of acting early in gestation at the distant tubal implantation site. Isolation of these immune effector cells from pregnancy tissues and study of their properties in functional assays may resolve these questions.

We thank Dr PCL Beverley for providing the antibody TG1 and theatre staff at the Clarendon Wing Theatres, Leeds General Infirmary, for obtaining fresh specimens.

\section{References}

1 Pijnenborg R, Dixon G, Robertson WB, Brosens I. Trophoblastic invasion of human decidua from 8-18 weeks of pregnancy. Placenta 1980;1:3-19.

2 Bulmer JN, Sunderland CA. Bone-marrow origin of endometrial granulocytes in the early human placental bed. J Reprod Immunol 1983;5:383-7.

3 Bulmer JN, Sunderland CA. Immunohistological characterisation of lymphoid populations in the early human placental bed. Immunology 1984;52:349-57.

4 Bulmer JN, Johnson PM. Macrophage populations in the human placenta and amniochorion. Clin Exp Immunol 1984;57: 393-403.

5 Bulmer JN, Johnson PM. Immunohistological characterization of the decidual leucocyte infiltrate related to endometrial gland epithelium in early human pregnancy. Immunology 1985;55: 35-44.

6 Clark DA. Materno-fetal relations. Immunol Lett 1985;9:239-47.

7 Augensen K. Unruptured tubal pregnancy at term with survival of mother and child. Obstet Gynecol 1983;61:259-61.

8 Earl U, Wells M, Bulmer JN. The expression of major histocompatibility antigens by trophoblast in ectopic tubal pregnancy. J Reprod Immunol 1985;8:13-24.

9 Earl U, Wells M, Bulmer JN. Immunohistochemical characterization of trophoblast antigens and secretory products in ectopic tubal pregnancy. Int J Gynecol Pathol 1986;5:132-42.

10 Dalchau R, Kirkley J, Fabre JW. Monoclonal antibody to a human leucocyte-specific membrane glycoprotein probably homologous to the leucocyte-common antigen of the rat. Eur $J$ Immunol 1980;10:737-44.

11 Beverley PCL, Callard RE. Distinctive functional characteristics of human $\mathrm{T}$ lymphocytes defined by $\mathrm{E}$ rosetting or a monoclonal anti-T cell antibody. Eur J Immunol 1981;11:329-34.

12 Rheinherz EL, Kung PC, Goldstein G, Schlossman SF. A monoclonal antibody reactive with the human cytotoxic/suppressor $\mathrm{T}$ cell subset previously defined by a heteroantiserum termed TH2. J Immunol 1980;124:1301-7.

13 Sunderland CA, Naiem M, Mason DY, Redman DWG, Stirrat GM. The expression of major histocompatibility antigens by human chorionic villi. $J$ Reprod Immunol 1981;3:323-31.

14 Guy K, Van Heyningen V, Cohen BB, Deane DL, Steel CM. Differential expression and serologically distinct subpopulations of human Ia antigens detected with monoclonal antibodies to Ia alpha and beta chains. Eur J Immunol 1982;12:942-80.

15 Bulmer JN, Earl U. The expression of class II MHC gene products by fallopian tube epithelium in pregnancy and throughout the menstrual cycle. Immunology 1987;61:207-13.

16 Pauerstein CJ, Croxatto HB, Eddy CA, Ramzy I, Walters MD. Anatomy and pathology of tubal pregnancy. Obstet Gynecol 1986;67:301-8.

17 Peters WM. Nature of "basal" and "reserve" cells in oviductal and cervical epithelium in man. J Clin Pathol 1986;39:306-12.

18 Bulmer JN, Wells M, Bhabra K, Johnson PM. Immunohistological characterization of endometrial gland epithelium and extravillous trophoblast in third trimester human placental bed tissues. Br J Obstet Gynaecol 1986;93:823-32.

19 Johnson PM, Bulmer JN. Uterine gland epithelium in human pregnancy often does not express detectable maternal MHC antigens but does express fetal trophoblast antigens. J Immunol 1984;132:1608-10.

20 Tawfik OW, Hunt JS, Wood GW. A major soluble factor produced by uterine cells during murine pregnancy is prostaglandin E2. J Reprod Immunol 1986;suppl:126.

21 Dallenbach-Hellweg G. Histopathology of the endometrium. 3rd ed. Berlin: Springer-Verlag, 1981:26.

22 Golander A, Zakuth V, Shechter Y, Spirer Z. Suppression of lymphocyte reactivity in vitro by a soluble factor secreted by explants of human decidua. Eur J Immunol 1981;11:849-51.

23 Daya S, Clark DA, Devlin C, Jarrell J, Chaput A. Suppressor cells in human decidua. Am J Obstet Gynecol 1985;151:267-70.

24 Daya S, Clark DA. Production of immunosuppressor factor(s) by preimplantation human embryos. Am $J$ Reprod Immunol Microbiol 1986;11:98-101.

25 Breen JN. A 21 year survey of 654 ectopic pregnancies. Am J Obstet Gynecol 1970;106:1004-16.

26 Sutton L, Mason DY, Redman CWG. Cells bearing class II MHC antigens in the human placenta and amniochorion. Immunology 1986;58:23-9.

Requests for reprints to: Dr U Earl, Department of Pathology, University of Leeds, Leeds LS2 9JT, England. 